\title{
Narrative Silences Between History and Memory in Schumann's Being Present: Growing Up in Hitler's Germany
}

Anne Rothe

Wayne State University

Follow this and additional works at: https://docs.lib.purdue.edu/clcweb

Dedicated to the dissemination of scholarly and professional information, Purdue University Press selects, develops, and distributes quality resources in several key subject areas for which its parent university is famous, including business, technology, health, veterinary medicine, and other selected disciplines in the humanities and sciences.

CLCWeb: Comparative Literature and Culture, the peer-reviewed, full-text, and open-access learned journal in the humanities and social sciences, publishes new scholarship following tenets of the discipline of comparative literature and the field of cultural studies designated as "comparative cultural studies." Publications in the journal are indexed in the Annual Bibliography of English Language and Literature (Chadwyck-Healey), the Arts and Humanities Citation Index (Thomson Reuters ISI), the Humanities Index (Wilson), Humanities International Complete (EBSCO), the International Bibliography of the Modern Language Association of America, and Scopus (Elsevier). The journal is affiliated with the Purdue University Press monograph series of Books in Comparative Cultural Studies. Contact: <clcweb@purdue.edu>

\section{Recommended Citation}

Rothe, Anne. "Narrative Silences Between History and Memory in Schumann's Being Present: Growing Up in Hitler's Germany." CLCWeb: Comparative Literature and Culture 11.1 (2009): <https://doi.org/10.7771/1481-4374.1418>

This text has been double-blind peer reviewed by $2+1$ experts in the field.

The above text, published by Purdue University Press (CPurdue University, has been downloaded 1470 times as of 11/ 07/19.

This document has been made available through Purdue e-Pubs, a service of the Purdue University Libraries. Please contact epubs@purdue.edu for additional information.

This is an Open Access journal. This means that it uses a funding model that does not charge readers or their institutions for access. Readers may freely read, download, copy, distribute, print, search, or link to the full texts of articles. This journal is covered under the CC BY-NC-ND license. 


\section{PURDUE}

UNIVERSITY PRESS <http://www.thepress.purdue.edu>

\section{CLCWeb: Comparative Literature and Culture}

ISSN 1481-4374 <http://docs.lib.purdue.edu/clcweb> Purdue University Press (C)Purdue University

CLCWeb: Comparative Literature and Culture, the peer-reviewed, full-text, and open-access learned journal in the humanities and social sciences, publishes new scholarship following tenets of the discipline of comparative literature and the field of cultural studies designated as "comparative cultural studies." In addition to the publication of articles, the journal publishes review articles of scholarly books and publishes research material in its Library Series. Publications in the journal are indexed in the Annual Bibliography of English Language and Literature (Chadwyck-Healey), the Arts and Humanities Citation Index (Thomson Reuters ISI), the Humanities Index (Wilson), Humanities International Complete (EBSCO), the International Bibliography of the Modern Language Association of America, and Scopus (Elsevier). The journal is affiliated with the Purdue University Press monograph series of Books in Comparative Cultural Studies. Contact: <clcweb@purdue.edu>

Volume 11 Issue 1 (March 2009) Article 6

Anne Rothe,

"Narrative Silences Between History and Memory in Schumann's Being Present: Growing Up in Hitler's Germany" <http://docs.lib.purdue.edu/clcweb/vol11/iss1/6>

Contents of CLCWeb: Comparative Literature and Culture 11.1 (2009)

<http://docs.lib.purdue.edu/clcweb/vol11/iss1/>

Thematic Issue New Work in Holocaust Studies

Edited by Louise 0 . Vasvári and Steven Tötösy de Zepetnek

Abstract: In her article "Narrative Silences Between History and Memory in Schumann's Being Present: Growing Up in Hitler's Germany" Anne Rothe analyzes Willy Schumann's 1991 memoir as an instance of a growing sub-genre among autobiographical writing on the Third Reich and the Holocaust, the Hitler Youth Generation memoir. Written in English for US-American college students, the memoir constructs a reactionary counter-memory to Holocaust discourse in order to exculpate ordinary Germans like himself not only from any responsibility for but any association with nazi crimes. In order to do so, Schumann not only largely omits the Holocaust but recasts the perpetrator/victim dichotomy via the political/personal divide into a history/memory dichotomy. Perpetrators are limited to a handful of leading nazis who inhabit the sphere of history together with "their" victims and are cast as the evil Other of decent ordinary Germans like Schumann who inhabit the realm of personal memory. Rothe explores the complex narrative strategies of silencing Schumann employs to convey his central notion of collective German innocence in what at first appears to be a naïve and straight-forward but turns out to be a highly manipulative and revisionist narrative. 
Anne Rothe,

"Between History and Memory in Schumann's Being Present: Growing Up in Hitler's Germany" page 2 of 12

CLCWeb: Comparative Literature and Culture 11.1 (2009): <http://docs.lib.purdue.edu/clcweb/vol11/iss1/6>

Thematic Issue New Work in Holocaust Studies. Ed. Louise O. Vasvári and Steven Tötösy de Zepetnek

\section{Anne ROTHE}

Narrative Silences Between History and Memory in Schumann's Being Present: Growing Up in Hitler's Germany

If we are more interested in autobiographical narratives as instances of what scholars in Germany have termed Alltagsgeschichte (history of everyday life) than for their artistic merit as aesthetic entities, we should examine narratives by non-professional writers, since these tend to be more indicative of ordinary people's everyday history than the verbal high-wire acrobatics of the professional literati. My discussion of Willy Schumann's non-canonical memoir, then, reflects the increasing significance of ordinary people's life narratives in oral history, narratology, Holocaust and auto/biography studies, particularly since the cultural studies turn in the humanities. It is also indicative of a growing interest in academia and among the general public, both German and US-American, in how ordinary Germans remember and emplot their everyday life in the Third Reich more than half a century later in light of their subsequently acquired knowledge about the Holocaust. By "ordinary" I refer in the following analysis not only to non-prominent status but specifically to Germans who were neither perpetrators nor victims but followers and bystanders. The increasing interest in such ordinary lives is not only reflected in such recent blockbuster movies as Der Untergang (Downfall) but also finds expression in a growing thematic sub-genre of autobiographical writing, the Hitler Youth generation memoir (e.g., von der Grün; Harig; Hermand; Mahlendorf; see also Leiser; Reich-Ranicki; Wicki; Schmitz).

Like all autobiographical writing, Schumann's memoir constitutes "a public performance of memory and [is] thus invested with contemporary interests" (Schmitz 152). Although unacknowledged, the author's core interest is to exculpate himself, his family, and all ordinary Germans not only from any individual or collective guilt for but any association with the crimes committed in the Third Reich. Schumann thus revives the notion that was first proposed by chancellor Konrad Adenauer and dominated the West German public sphere in the 1950s some three decades later. To achieve his aim, Schumann splits the world of his childhood and adolescence into two realms: the public sphere of history and the personal sphere of memory, which are separated by an unbridgeable void. The sphere of history is populated by the perpetrators, above all Hitler himself and a small number of leading nazis, and "their" victims. Holocaust and Nazi victims in general are largely absent from the text because Schumann seeks to claim victim status for ordinary Germans like himself and must therefore hide the fact that this subject position is already occupied. Perpetrators are cast as the evil Other of the ordinary Germans and ascribed sole responsibility not only for the crimes committed in the Third Reich, but also -- and most significantly -- for the suffering of ordinary Germans. The later, who inhabit the realm of personal memory, are portrayed as misled and manipulated but otherwise decent people who had to suffer the devastating consequences of nazi politics when many of them were killed in bombing raids, during the flight and expulsion from the East, and as Wehrmacht soldiers. In an attempt to transform collective German responsibility for nazi crimes into a discourse of collective German innocence and victimization, Schumann thus recasts the canonical perpetrator/victim dichotomy by recourse to the public/private division into a history and memory dichotomy.

In the following, I explore five interrelated narrative strategies Schumann utilizes in order to exculpate ordinary Germans: 1) he employs a pseudo-positivist rhetoric of fact and simulates narrative omniscience to authorize his narrative voice as unquestionable; 2 ) he excludes virtually all intertextual and intermedial references to other cultural artifacts about the Third Reich and the Holocaust; 3) he largely displaces the Holocaust from the text; 4) he replaces Holocaust discourse with a narrative about the innocence and victimization of ordinary Germans; and 5) he employs the discourse of German victimization and innocence to replace the notion of collective and individual German guilt. 
Anne Rothe,

"Between History and Memory in Schumann's Being Present: Growing Up in Hitler's Germany" page 3 of 12

CLCWeb: Comparative Literature and Culture 11.1 (2009): <http://docs.lib.purdue.edu/clcweb/vol11/iss1/6>

Thematic Issue New Work in Holocaust Studies. Ed. Louise O. Vasvári and Steven Tötösy de Zepetnek

1) Schumann employs a pseudo-positivist rhetoric of fact, objectivity and truth in order to establish an authority over the depicted events no autobiographical author-narrator can logically possess, that of an omniscient narrator. According to Dorrit Cohn, only third-person narrators can be omniscient because they constitute a disembodied narrative medium that, unlike a first-person narrator, cannot be ascribed human characteristics. As a consequence, stories told by an omniscient, third-person narrator appear to be objective, complete and fully reliable. Autobiographers, however, are firstperson narrators and as such they share their human characteristics, most importantly a selective human memory which adjusts how past events are remembered and hence narrated based on present world views (see Schacter). Given the autobiographers' subjectivity, then, they cannot be omniscient narrators. Schumann nevertheless simulates omniscience and his sporadic coy admission of uncertainty about a particular detail, rather than relativizing his claim of total knowledge and absolute reliability, actually strengthens it, as it implies that all else in the text does fulfill his claim to omniscience and objectivity. However, he modeled his narrative less on omniscient literary narration than on the grand histories of the nineteenth century, the founding father of which, German historian Leopold von Ranke, he quotes in the preface when he claims that he too will tell history "as it actually happened" (ix).

In order to boost his claim of authority further, Schumann ascribes himself the subject position of witness and asserts that only historical witnesses can write history "as it actually happened." Because the concept of "witness," like that of "testimony," entered Holocaust discourse as a legal term and to non-jurists thus initially implied factual reliability, current scholarship in both legal (see Loftus) and Holocaust studies (see Laub) as well as research on memory in cognitive psychology (see Schacter) have refuted the common notion that eyewitnesses can know and testify to their own subjective experience whether traumatic or mundane with total factual accuracy. And most recently, Annette Wieviorka critiqued the increasingly dominant claim in what she terms "the era of the witness" that unlike scholarly historiography which lacks the experiential knowledge of the eyewitness, the accumulated survivor testimony constitutes an account of the past "as it actually happened" precisely because human memory is fallible and, unlike historiographic accounts, neither verifiable nor falsifiable. To a scholar, then, Schumann's invocation of the subject position of historical witness not only contradicts his claim to objectivity but also implicitly invokes the Holocaust, neither of which is in his interest. But Schumann's implied readers are, as he states in the preface, US-American college students, which is why he wrote the memoir in English and published it with a university press in the U.S. The readers inscribed in the text are thus neither familiar with representations of the Third Reich -- the cultural dominance of Holocaust discourse is coupled with ignorance as to even the most significant historic specificities in the U.S. (see Cole; Novick) -- nor with recent scholarship in legal studies and psychology. To Schumann's implied reader witness status will most likely evoke the legal eyewitness concept of television courtroom dramas as someone who can testify to what "actually happened" and will thus understand it as supporting rather than contradicting the author's omniscience claim. Schumann's implied audience is also not familiar with Holocaust research and therefore cannot realize that the witness concept invariably invokes the Holocaust. It may also well be that Schumann himself was unaware of the intrinsic contradiction in his authority claim between nineteenth-century Rankean objective history and the current historical witness concept, and the fact that the latter invokes the holocaust. It is seems too risky a narrative maneuver to undertake with full awareness.

Schumann claims the subject position of historical witness and simulates omniscience to establish his narrative voice as objective and unbiased in order to authorize his exculpation of ordinary Germans and concomitant silencing of holocaust discourse. However, these two core narrative strategies in and of themselves also already silence the holocaust. For example, Schumann states as his reason for writing the memoir that he wanted to correct the "the real knowledge in this country [the U.S]" (ix) with respect to the Third Reich, which he considers "fragmentary, sporadic, and one-sided" (ix). While 
Anne Rothe,

"Between History and Memory in Schumann's Being Present: Growing Up in Hitler's Germany" page 4 of 12

CLCWeb: Comparative Literature and Culture 11.1 (2009): <http://docs.lib.purdue.edu/clcweb/vol11/iss1/6>

Thematic Issue New Work in Holocaust Studies. Ed. Louise O. Vasvári and Steven Tötösy de Zepetnek

he does not explain what he means by "one-sided," it can only be a reference to the Holocaust as the dominant feature in US-American discourse of the Third Reich. By criticizing this unidentified discourse as "fragmentary, sporadic and one-sided," Schumann implicitly claims that his own account will be the opposite: complete, total, and objective. Not naming the cultural memory of the holocaust in the U.S. as the discourse against which he wrote his memoir not only silences this discourse but also already blatantly violates his claim to objectivity. Schumann's rhetoric modeled on Rankean positivist historiography that purports to objectively present only "the facts" also intrinsically silences holocaust discourse because it necessarily excludes any reflection on key issues in holocaust studies: the ethics and aesthetics of representation and the role of the memoir as the primary genre for survivor narratives in addition to video testimony. Last but not least, Schumann's rhetoric of objectivity inherently silences the holocaust because it necessitates the virtual absence of a not only critical and reflective but also of an emotional narrating self, as its presence would invoke subjectivity. Hence, it necessitates the absence of mourning Holocaust victims.

2) Schumann writes his memoir as if childhood and adolescence in the Third Reich -- or any other aspect of it, including the Holocaust, for that matter -- has essentially never been depicted. In eliminating references to the vast array of Holocaust representations -- including fiction, memoirs, documentaries, feature and television films, photography, music, exhibitions, not to mention scholarship -he severs his story from its intertextual and intermedial context. This lack of reference to thematically related cultural artifacts is particularly significant, since Schumann's text not only constitutes a memoir but also an instance of academic discourse as it possess key features of academic writing: it was written by an academic, it includes endnotes, and it was published by a university press. As a Smith College professor of German Schumann should at least be familiar with canonical representations of the Third Reich in German culture as Horváth's Jugend ohne Gott (Youth without God; published in English as The Age of the Fish), Lenz's Die Deutschstunde (The German Lesson), Wolf's Kindheitsmuster (Patterns of Childhood) and Wicki's film Die Brücke (The Bridge) as well as with equally famous German Holocaust representations, like the plays Die Ermittlung (The Investigation) by Peter Weiss and Der Stellvertreter (The Deputy) by Rolf Hochhuth, the poetry of Nelly Sachs and Paul Celan, and Jurek Becker's novel Jakob der Lügner (Jacob the Liar). This motivated absence not only silences Holocaust discourse but furthermore serves to strengthen the author's simulated omniscient narrative authority, as no alternative voices are present in his memoir.

The only exception to this virtually all-encompassing silence is a page-long discussion of Carl Zuckmayer's contentious play Des Teufels General (The Devil's General), which demonizes Hitler as the Devil himself. In Schumann's interpretation, the main character, who knowingly served Evil and commits suicide to atone for this sin, becomes a tragic hero, while the resistance fighter is cast dangerously close to the role of a traitor. The Holocaust is absent from the play. It thus fits Schumann's conceptualization of the Third Reich and is therefore discussed at considerable length. However, this discussion includes a most telling silence: Schumann neglects to mention that Zuckmayer emigrated from nazi Germany because according to the Nuremberg Laws he was half-Jewish.

3) As Schumann's thesis of ordinary German innocence requires dichotomizing life in the Third Reich, the realms of history and memory he constructs cannot intersect. While the world of history is inhabited by both the perpetrators -- a small number of nazi criminals who committed the crimes and thus bear sole responsibility for them -- as well as their victims, the world of personal memory is made up of decent, ordinary Germans who had to suffer the disastrous consequences of nazi politics. Therefore, Schumann has to exclude the description of every-day life in his home town, Brunsbüttel, from his memoir, as this is precisely the realm where the events that historians will subsequently write about and the sphere of regular people's personal memories intersect. He tries neither to find out who among the local people was involved in the nazi power structure and who committed crimes, nor what happened to Brunsbüttel's supposedly sole Jew, his half-Jewish daughter and "Aryan" wife. Schu- 
Anne Rothe,

"Between History and Memory in Schumann's Being Present: Growing Up in Hitler's Germany" page 5 of 12

CLCWeb: Comparative Literature and Culture 11.1 (2009): <http://docs.lib.purdue.edu/clcweb/vol11/iss1/6>

Thematic Issue New Work in Holocaust Studies. Ed. Louise O. Vasvári and Steven Tötösy de Zepetnek

mann's silence further encompasses what happened during the so-called Reichskristallnacht in his hometown, where the nearest book burning took place and where the nearest concentration camp -probably one of Neuengamme's small satellite camps -- was located. While Schumann may not have been aware of these events as the experiencing self -- he was born in 1927 and was thus between six and eighteen years old at the time -- the ignorance of the narrating self who remembers his childhood and adolescence some four decades later is clearly self-serving. Since it would expose as untenable the history/memory dichotomy on which his exculpatory belief in the innocence of ordinary Germans rests, the author omits the local history of his hometown in the Third Reich. In withholding this knowledge from his implied US-American student readers Schumann propagates self-serving ignorance, a rhetorical strategy rather reminiscent of nazi propaganda.

Schumann also displaces and thus intentionally silences the Holocaust in his brief reflections on nazi language when he omits mention of the most famous study on the subject, LTI (the acronym stands for the Latin lingua tercii imperii) by the German-Jewish professor of French Victor Klemperer. Klemperer survived the Third Reich in dire circumstances due to his status as a spouse in a "mixed marriage." While his famous diaries, Ich will Zeugnis ablegen bis zum Letzten (I Will Bear Witness) were published only after Schumann's memoir, LTI was published in both East Germany (1947) and West Germany (1969) and well known among scholars of German. Not mentioning LTI in his discussion of nazi language practices not only effaces Klemperer as a Holocaust survivor but also severs the connection established through nazi practices of language between the mundane life of ordinary Germans and nazi ideology and crime. For the same reason, the only terms Schumann refers to as instances of nazi language are military ones; for example Frontverkürzung, an euphemism for "retreat" and the revival of the archaic term Feldzug ("military campaign"), while both the racist and antiSemitic vocabulary of Social Darwinism and Eugenics and infamous nazi euphemisms like Endlösung ("Final Solution") are excluded. His equally brief discussion of nazi music is limited to traditional German folk songs and a song promoting global conquest, omitting mention of the most notorious and widely known -- particularly among Wehrmacht soldiers -- anti-Semitic song verse, which celebrates slashing a knife into a Jewish body so that Jewish blood will gush out.

The Holocaust is also silenced through displacement when Schumann follows nazi ideology in excluding Jews (as well as all other "non-Aryans" and political opponents) whenever he refers to "Germans" or even to "people." For example, he writes: "Many historians today consider these years, the mid-thirties, as the high point of amicable and harmonious relations between the Third Reich and the rest of the world. Many Germans at the time shared this opinion. There seemed to be visible progress in all areas. People were regaining some of their self-respect, self-confidence, and pride. It was fun again being German" (14). While the "many historians" remain unnamed and their claim of good relations between the Third Reich and the rest of the world thus unverifiable, neither Jews nor political opponents could have considered the mid-1930s a time in which "it was fun again being German," nor would they have seen reason to regain "some of their self-respect, self-confidence, and pride." After all, the first concentration camp was opened in 1933 at Dachau and vast numbers of anti-Jewish laws -- most infamously the Nuremberg Laws -- were enacted in the mid-1930s (see Dawidowicz), the burning of books by "undesirable" authors and their removal from libraries and book stores took place in 1933 as did the boycott of Jewish businesses, and the so-called Reichskristallnacht occurred in 1938. And in segregating Jewish and Non-Jewish Germans into Jews and Germans, Schumann's rhetoric mirrors the nazi practice of ghettoization. He even goes so far as to de-Germanize the probably most widely known Holocaust victim when he refers to "the persecution of Dutch Jews, later immortalized by the fate of a young Dutch girl, Anne Frank" (86). While she wrote her diary in Dutch, Anne Frank and her family were of course German Jews who had fled to Amsterdam in the 1930s.

While Schumann sporadically refers to "the Jews" as a disembodied collective entity, not a single Jewish individual appears in the text. As an archival photo of anonymous subjects, the single picture 
Anne Rothe,

"Between History and Memory in Schumann's Being Present: Growing Up in Hitler's Germany" page 6 of 12

CLCWeb: Comparative Literature and Culture 11.1 (2009): <http://docs.lib.purdue.edu/clcweb/vol11/iss1/6>

Thematic Issue New Work in Holocaust Studies. Ed. Louise O. Vasvári and Steven Tötösy de Zepetnek

of Jews in the memoir offers a stark contrast to the book's photographic portrayals of "ethnic" Germans, as even the most minor of these characters is named and thus individualized. The photograph, which shows concentration camp victims, is furthermore of exceptionally poor quality. Unlike all other images in the book, this one must have originally been printed on coarse paper such as newsprint. Therefore, even the faces of the two men in the foreground of this photograph are devoid of any depth, showing no shades of grey but rather appearing as patches of black and white. Even someone who knew these men well would have difficulty recognizing them. Using a picture of unidentified subjects that is of distinctly worse quality than the book's other photographs depicting "Aryan" Germans exhibits a continuity of nazi ideology and practice, as the photograph subtly represents Jews as inferior to "Aryans."

Schumann also betrays his total disregard for Holocaust victims as individuals and fellow humans in the single scene of the memoir in which an individual Jew is mentioned. When Schumann and his mother are shopping for the last time in a store owned by Mr. T., the Jewish store owner is not only not named but he is also absent from the scene, as is his half-Jewish daughter. It is the non-Jewish wife who serves the customers. While the experiencing self of course cannot be blamed for this, the lack of reflection by the narrating self on this absence constitutes a telling metaphor for the absence of Holocaust victims from Schumann's narrative. The author does also not acknowledge the fact that, in not going back to this store, his parents contributed to the social and economic exclusion of German Jews from everyday life. Not going back, whether out of fear or willful ignorance, amounts to an active participation in the anti-Semitic politics of the Third Reich on the part of Schumann's parents. And neglecting to find out what happened to Mr. T. and his family constitutes a continuity of this self-serving ignorance on Schumann's part and thus an instance of what Ralph Giordano termed "die zweite Schuld" ("the second guilt").

Schumann furthermore displaces Jews and the Holocaust from his memoir by his silence about meeting any Jews after emigrating to the U.S. and on how the nazi propaganda he experienced for twelve years -- as both member and instructor in the Hitler Youth organization -- subsequently influenced his relations with Jews. The largely chronological memoir ends in the early 1950s, the point at which he considered his personal Vergangenheitsbewältigung over and done with. Hence, his narrative ends most likely before Schumann got to know any Jews. But ending the memoir at that point and not interrupting its chronological structure means that the author never mentions doing his doctoral studies in New York, i.e., one of the centers of US-American Jewry, together with German-Jewish emigrants such as Guy Stern -- my predecessor at Wayne State University to whom I dedicate this article and who provided the following names -- Peter Heller, Walter Sokel, and Inge Halpert.

The last strategy of silencing the Holocaust differs somewhat from the previous ones because it does not entail dis-placement -- i.e., intentionally excluding a subject from a context in which its presence is made highly probable by the fact that thematically related cultural artifacts do include it -- but, rather, mis-placing it in a wrong context. As already mentioned, the text contains a number of photographs. They fall into two categories: private snapshots of Schumann himself, his family, and their lives in the Third Reich and archival pictures of major historical events, e.g., a book burning, Hitler shaking hands with Hindenburg upon becoming Reich chancellor, and the above-mentioned picture of concentration camp victims. The photographs reflect the text's analogous dichotomy between the realms of memory and history. In both his verbal and pictorial representations, Schumann thus misplaces Holocaust victims from their discursive position in the victim/perpetrator dichotomy into his alternative history/memory dichotomy. In other words, the victims are mis-placed alongside the perpetrators in the sphere of history and separated by an unbridgeable void from the world of personal memory inhabited by decent ordinary Germans like the Schumanns.

4) Schumann not only silences the Holocaust by displacing it almost entirely from the memoir but also by replacing it with detailed descriptions of ordinary Germans' mundane life. For example, he de- 
Anne Rothe,

"Between History and Memory in Schumann's Being Present: Growing Up in Hitler's Germany" page 7 of 12

CLCWeb: Comparative Literature and Culture 11.1 (2009): <http://docs.lib.purdue.edu/clcweb/vol11/iss1/6>

Thematic Issue New Work in Holocaust Studies. Ed. Louise O. Vasvári and Steven Tötösy de Zepetnek

scribes his annual summer vacations at the idyllic Baltic Sea in great detail, never mentioning that Jews had been prohibited from using public beaches and pools since 1936. Similarly, the normalcy with which he describes the lives of German children replaces and hence silences the experiences of Jewish children, whose lives at the time were characterized precisely by the total lack of such normalcy: "my friends and I had grown up as normal children in normal middle-class homes ... We had our own rooms or shared them with siblings. We had been provided with three meals every day prepared by our mothers. On six days of the week there had been the daily routine of school from eight o'clock in the morning to one or two in the afternoon, a great deal of homework in the afternoon and at night, and DJ [Deutsches Jungvolk] or HJ [Hitlerjugend] duties every Wednesday and Saturday afternoon. There was not much free time except during school holidays. When we were not occupied, we went to the movies, engaged in sports (soccer, gymnastics, field handball), and we pursued all activities typical of children and adolescents" (120). Instead of reflecting on the systematic exclusion of Jews from everyday life in the Third Reich, Schumann's narrative, then, continues nazi ideology and practice in their exclusion.

Schumann exhibits a similar continuity when he uses nazi language without reflecting on and distancing himself from it. For example, he employs the phrase of only following orders, famously invoked to justify mass murder by nazi defendants at the Nuremberg Trials, in utterly mundane situations: In discussing how families were separated when children were sent from cities threatened by air raids to rural areas, he writes that "orders were orders, and they had to be carried out" (110). He repeats this phrase almost verbatim in a similarly benign context, a passage recounting a squabble between different groups of anti-aircraft gunners that ends with the realization that "we, just like they and all Germans, were following orders, and orders were there to be carried out" (124). His use of language not only indicates that Schumann would have apparently followed any order at the time but also indicates continuities in his views of the Third Reich and the Holocaust more than forty years later and thus a total lack of reflection on the crimes that were committees simultaneously to his largely idyllic nazi childhood. He is also silent on the fact that the Jungvolk and Hitlerjugend uniform, which he states he proudly wore, was modeled on that of the SA (see Keeley) and that the insignia of the Jungvolk, which appeared on the uniform sleeves and flag, was a victory rune, the symbol that, when doubled, produces the insignia of the SS. In other words, the uniform he so proudly wore as a boy without distancing himself as narrator from this childhood enthusiasm resembles those of the two infamous nazi paramilitary organizations. In fact, the colloquial term for the SA was Braunhemden ("brown-shirts"). While he mentions that SA men "guarded" the entrance to Mr. T.'s store on the day of the boycott of Jewish businesses and took note of everyone who broke the boycott and entered the store, he relates their active but local and small-scale involvement in the Holocaust to neither of the facts that he himself wore essentially the same uniform nor that his own father was a member of the $\mathrm{SA}$, as either would have ruptured his history/memory dichotomy.

Throughout the memoir, the Holocaust is furthermore silenced by replacing it with a discourse of ordinary German life when Schumann uses key vocabulary of Vergangenheitsbewältigung such as "camp," "perpetrator," "guilt," and "survival" solely in their everyday meanings, thus omitting their specific Holocaust significance. For example, "camp" abounds in his text, yet the word only refers to the various Jungvolk and Hitler Youth camps Schumann attended. "Concentration camps" are mentioned in passing and without any reflection on the relationship between the two kinds of "camps," since this too would have disrupted the history/memory dichotomy on which his claim to German innocence rests. The single use of the term "perpetrator" occurs not in the context of crimes committed in the Third Reich or even in Schumann's brief and deeply conservative-revisionist discussion of the Nuremberg Trials. Instead, the author refers to himself and his friends as "we perpetrators" (126) in a telling attempt at humor that betrays the totality of his suppression, when a teacher discovers the boys playing cards instead of doing their homework. Similarly, the author uses the word "guilty" only 
Anne Rothe,

"Between History and Memory in Schumann's Being Present: Growing Up in Hitler's Germany" page 8 of 12

CLCWeb: Comparative Literature and Culture 11.1 (2009): <http://docs.lib.purdue.edu/clcweb/vol11/iss1/6>

Thematic Issue New Work in Holocaust Studies. Ed. Louise O. Vasvári and Steven Tötösy de Zepetnek

once: to express that he did not feel guilty when he stole a bicycle on his way home at the end of the war, and "survive" and "survival" are only used to describe the struggles of Germans at the end of the war.

Schumann also suppresses the Holocaust by replacing it with a discourse of the every-day life of ordinary Germans when his sole focus with regard to the Holocaust is its negative effect on the image of precisely those ordinary Germans: "the fate of the Jews under the Third Reich ... has tainted the German image in world history probably forever" (26). What matters to Schumann, then, is not that some eleven million people, including some six million Jews, were brutally persecuted and murdered and European-Jewish culture was extinguished, but that these events have "tainted the German image." He also betrays his lack of empathy for the victims of the Third Reich in his detailed discussion of the attempted assassination on Hitler: "The attempt to kill Adolf Hitler, to topple the NS [national socialist] regime and replace it with a new government, was absolutely necessary. The honor of the German people was at stake -- the good name of the German people and the place of Germany in the family of civilized and humane countries" (129-30). Not only does he again exclude all "non-Aryans" from "Germans," but he exhibits either utter ignorance of Holocaust history or a total lack of moral and ethical integrity in considering the millions of Jews and other nazi victims already killed by July 1944 as not reason enough to damage "the honor" and "the good name of the German people." His discussion of the assassination attempt even ignores the question of whether its success and a concomitant coup d'état would even have ended the Holocaust. To Schumann, such a course of events would have exonerated all Germans, apparently including all but the highest nazi charges, from any responsibility and guilt. Since the assassination attempt failed, "the insanity and the devastation of the war continued for almost nine more months" (130), as did the Holocaust, which Schumann again fails to mention. He concludes the discussion of the assassination attempt as follows: "One of the most moving experiences of my life was my 1967 visit to Berlin-Plötzensee, the memorial for the participants of the July 20 action. I stood in the stark, empty hall which in 1944 had served as the place of execution for many of the conspirators, where they were hanged with piano wires on meat hooks to prolong their agony" (130).

The conspirators, many of whom were high-ranking Wehrmacht officers and nazi charges and thus perpetrators for eleven years, are recast as tragic heroes and victims and thereby entirely exculpated. Schumann's sympathy, empathy, and identification are clearly with these perpetrators-cum-victims, not the Holocaust victims, whose suffering and victim status he silences by replacing it with that of the comparatively minute number of high-ranking nazis and Wehrmacht officers. His most moving experience was not a visit to a concentration camp memorial or an encounter with Holocaust survivors, experiences he never mentions and may never have sought out, but his visit to the Plötzensee memorial. Mourning for the Holocaust victims is silenced by replacing it with mourning for the conspirators of what he terms the July 20th action. In employing the term "action," Schumann not only inadvertently employs nazi terminology again but even casts the failed assassins in the subject position of Holocaust victims as Aktion was the euphemistic nazi term denoting mass killings by SS Einsatzgruppen ("operational units" functioning as mobile killing squads). The memoir, then, silences the suffering and death of Holocaust victims by replacing it with both the mundane life of ordinary Germans and the suffering and death of a small group of leading nazis and army officers.

5) While Schumann employs both displacement and replacement to silence Holocaust discourse, he relies entirely on replacement -- a form of silence partially hidden by other discourse -- to suppress German guilt. Throughout the memoir, his detailed discussion of ordinary Germans' innocently mundane lives which almost entirely replaces the Holocaust similarly replaces any mention of German guilt and responsibility. While in Being Present "the Nazis" committed "their" crimes in the sphere of history and thus in total isolation from the realm of ordinary Germans' lives -- who thus also knew nothing about the crimes, let alone participated in them, and can therefore not be held responsible -- Schu- 
Anne Rothe,

"Between History and Memory in Schumann's Being Present: Growing Up in Hitler's Germany" page 9 of 12

CLCWeb: Comparative Literature and Culture 11.1 (2009): <http://docs.lib.purdue.edu/clcweb/vol11/iss1/6>

Thematic Issue New Work in Holocaust Studies. Ed. Louise O. Vasvári and Steven Tötösy de Zepetnek

mann does once include someone he himself labels a nazi within the sphere of memory: "Even Frau $\mathrm{E}$. ... the most dedicated National Socialist on our street ... shook her head ... and said ... 'For heaven's sake, that [the Reichskristallnacht pogrom] was not necessary.' This remark of Frau E. may sound naïve today in our post-Holocaust age, but who among these decent citizens who all their lives had been accustomed to law and order could have imagined at that time the ghastly plans and projects growing in the mind of the NS [national socialist] leadership?" (28). Schumann, then, even includes "the most dedicated National Socialist on our street" among those he deems "decent citizens" and categorically distinguishes from "the NS leadership" thus simultaneously absolving all "small fry" nazis and ascribing to himself the subject position of innocent from which he can grant such an absolution.

Schumann not only transvalues minor nazis like Frau E. into "decent citizens" but in his attempt to silence German guilt and responsibility even recasts all ordinary Germans as victims whose naïve decency was manipulated by "the NS leadership" and who died in the bombing raids and as Wehrmacht soldiers. However, in order to conceptualize ordinary Germans purely as victims, Schumann must not only silence the Holocaust, but also the historical context of the bombings of German cities, because it was after all the German air force which first bombed civilian centers. While the bombing of Rotterdam and London are mentioned in passing, this occurs outside of the context of the bombing of German cities. Similarly, in order to conceive of his acquaintances who fell as Wehrmacht soldiers as victims, Schumann suppresses the fact that the Wehrmacht not only fought a war of aggression, but also participated in crimes against civilians on the Eastern front (see, e.g., Hamburger Institut für Sozialforschung; Browning). Furthermore, while no individual nazi victims are named in the memoir, numerous German men who fell at the front are named and thus acknowledged as dying individual deaths (e.g., Lothar T., Werner D., Gerd F.). And besides the July 20 conspirators, fallen German soldiers are the only dead Schumann comes close to mourning. He even goes so far as to present the Waffen SS as victims -- paralleling the highly controversial gesture of the 1985 visit to the Bitburg cemetery by German chancellor Helmuth Kohl and U.S. president Ronald Reagan -- when he shows empathy with defeated Waffen SS members, and in doing so suppresses their horrendous crimes and vast number of victims, essentially exculpating them (167). Ordinary Germans, including minor nazis like Frau E., Wehrmacht soldiers and even Waffen SS members are, then, not presented as perpetrators but as decent Germans and even as victims based on the false presupposition that everyone who suffers or dies a premature death is a victim and therefore innocent. In turning perpetrators and followers into victims Schumann silences German guilt by replacing it with a narrative of German suffering and innocence, a discourse transformation that would become dominant in the German public sphere after unification (see Niven).

Similarly, Schumann silences German guilt when he discusses the Nuremberg Trials solely as show trials staged by the victors. He even suggests that the verdicts were unlawful because the military tribunal included Soviet judges and prosecutors, despite the fact that the crimes committed by the Stalinist regime were compatible to those of the nazis. Although this discussion does not reference the so-called Historikerstreit (historians' debate), which occurred in the late 1980s while Schumann was writing his memoir, in comparing nazi and Stalinist crimes to argue that the former were not unique in history, which supposedly makes them less horrid and the perpetrators less guilty, Schumann positions himself, whether knowingly or not, on the revisionist-conservative side of the debate. Furthermore, he considers the trials unlawful because they were based on laws that did not exist in the Third Reich but were imposed later by the victors. Hence, he does not acknowledge that the entire legal system of the Third Reich was criminal as it constituted the juridical-bureaucratic backbone to the crimes. Last but certainly not least, there is no mention of nazi crimes and guilt in Schumann's account of the Nuremberg Trials.

Schumann replaces German guilt with self-absolution based on destiny and geographical location. This idea is so central to his thinking that it is invoked at the two most prominent places of any text, 
Anne Rothe,

"Between History and Memory in Schumann's Being Present: Growing Up in Hitler's Germany" page 10 of 12

CLCWeb: Comparative Literature and Culture 11.1 (2009): <http://docs.lib.purdue.edu/clcweb/vol11/iss1/6>

Thematic Issue New Work in Holocaust Studies. Ed. Louise O. Vasvári and Steven Tötösy de Zepetnek

the first and last page. Germans were "a people who, because of their central geographical location, were destined to play a major role in history" (ix). This is not only a teleological and therefore untenable view of history, but it sweepingly absolves all Germans, all nazis included, from any responsibility for both world wars and for the crimes committed in the Third Reich. Schumann again invokes geography on the last page, this time to absolve himself of any wrongdoing. He casually mentions that, as an exchange student at a U.S. university in 1950, he stood in an enrollment line with army veterans, prompting the administrator to tell him: "You are in the wrong line. You were in the wrong army." He continues: "In later years I have often retold this little scene, but always with a small addendum to myself: 'Right you are, Ms. Unknown Secretary, but you could have added, 'and in the wrong country at the wrong time'" (198). Thus Schumann attempts to absolve himself of guilt and responsibility by invoking chance, which caused him to be in the wrong geographical location at the wrong time in history. Nowhere in his memoir does he assume any responsibility for his own actions or for those of the Germans as a collective, although as a member and instructor of the nazi organizations Jungvolk and Hitlerjugend he had actively participated in and fully believed nazi ideology and practice to the extent that he still trained to become a Wehrmacht officer and continued to believe in a final German victory in April 1945. While he was not guilty by deed because the war ended before he finished his officer training course, he was what could be termed guilty by thought and conviction. But he neither contemplates the fact that, had the war lasted longer he may well have become a perpetrator if, for example, he had been ordered to kill civilians on the Eastern front, nor does he consider himself, his family, or any other ordinary "decent Germans" guilty or in any way responsible for the crimes committed in the Third Reich. This silence is particularly noticeable despite the discourse of German innocence and even victimhood behind which it is hidden because critical reflections about collective German guilt and responsibility are made contextually probable by, for example, the powerful admission of Christa Wolf's narrator in Kindheitsmuster (Patterns of Childhood): "I would have. I might have. I could have. Done it. Obeyed orders" (230) ("Ich hätte. Ich könnte. Ich würde. Getan haben. Gehorcht haben" [295]).

Last, but not least, Schumann denies German guilt by replacing it with detailed, repeated assertions that his family was not anti-Semitic. Given the centrality of racist anti-Semitism in the Third Reich, the facts that his father joined not only the nazi party but also a subdivision of the SA immediately after Hitler was appointed Reich chancellor in 1933, and that Schumann himself was not only eager to join the Jungvolk and subsequently the Hitlerjugend but was also an instructor in these organizations, he has a lot of re-interpreting to do. Discussing his father, he writes: "I like to believe that it was also the flagrant anti-Semitism of the national socialists that repelled him. I certainly never heard a single anti-Semitic remark from my father or my mother. That simply was not done in our family" (9). This statement constitutes a carefully constructed piece of rhetoric. While -- precisely because the subject was not discussed -- Schumann cannot know anything about his father's attitude toward Jews, he nevertheless attempts to create the impression that his father, despite his membership in both the nazi party and the SA, was not an anti-Semite. However, the phrase "that simply was not done in our family" reveals that this supposed lack of anti-Semitism, if it indeed existed, was not grounded in ethical and moral conviction but rather in middle-class good taste and manners. But since actions speak louder than words, they certainly also speak louder than silences. While Schumann claims a "relative failure and ineffectiveness of the NS [national socialist] propaganda to turn us young people into rabid anti-Semites" (29), he does admit that he and his fellow Jungvolk and Hitlerjugend members believed in nazi ideology to the extent that he still expected final victory in April 1945. Since nazi ideology was so entirely infused with the supposed superiority of the "Aryan race," it seems unlikely that someone could believe in it without being influenced by its racism and anti-Semitism.

In conclusion, Schumann's memoir represents the mindset of a Hitler Youth generation member which while not outright a text of Holocaust denial comes dangerously close to such. This frame of 
Anne Rothe,

"Between History and Memory in Schumann's Being Present: Growing Up in Hitler's Germany" page 11 of 12

CLCWeb: Comparative Literature and Culture 11.1 (2009): <http://docs.lib.purdue.edu/clcweb/vol11/iss1/6>

Thematic Issue New Work in Holocaust Studies. Ed. Louise O. Vasvári and Steven Tötösy de Zepetnek

mind has been self-critically analyzed by Christa Wolf in the canonical fictionalized autobiographical account of her own experience of growing up in the Third Reich as "patters of childhood." It describes a Weltanschauung acquired precisely in the mundane, every-day life activities as a child and adolescent in the Third Reich that, which, even though its overt content has been rejected, as a mind set covertly still effects the thoughts, memories and emotions of the Hitler Youth generation decades later.

\section{Works Cited}

Browning, Christopher. Ordinary Men: Reserve Police Batallion 101 and the Final Solution in Poland. New York: HarperCollins, 1992.

Cohn, Dorrit. Transparent Minds: Narrative Modes for Presenting Consciousness in Fiction. Princeton: Princeton UP, 1978.

Cole, Tim. Selling the Holocaust: From Auschwitz to Schindler. How History is Bought, Packaged, and Sold. New York: Routledge, 2000.

Dawidowicz, Lucy. A Holocaust Reader. New York: Behrman House, 1997.

Felman, Shoshana, and Dori Laub. Testimony: Crises of Witnessing in Literature, Psychoanalysis and History. New York: Routledge, 1992.

Giordano, Ralph. Die zweite Schuld oder von der Last Deutscher zu sein. München: Knaur, 1990.

Grün, Max von der. Wie war das eigentlich? Kindheit und Jugend im Dritten Reich. München: dtv, 2003.

Hamburger Institut für Sozialforschung, ed. Verbrechen der Wehrmacht. Dimensionen des Vernichtungskrieges 1941-1944. Ausstellungskatalog. Hamburg: Hamburger Edition, 2002.

Harig, Ludwig. Weh dem, der aus der Reihe tanzt. München: Hanser, 1990.

Hermand, Jost. Als Pimpf in Polen: Erweiterte Kinderlandverschickung 1940-1945. Hamburg: Fischer, 1993.

Hochhuth, Rolf. Der Stellvertreter. Reinbek: Rowohlt, 1963.

Horváth, Ödön von. Jugend ohne Gott. Frankfurt: Suhrkamp, 1983.

Keeley, Jennifer. Life in the Hitler Youth. San Diego: Lucent Books, 1999.

Klemperer, Victor. LTI. Notizbuch eines Philologen. Leipzig: Reclam, 1999.

Klemperer, Victor. Ich will Zeugnis abegen bis zum Letzten. Vol. I Tagebücher 1933-1941, Vol. II Tagebücher 1942-1945. Berlin: Aufbau, 1995.

Laub, Dori. "An Event Without a Witness: Truth, Testimony, and Survival." Testimony: Crises of Witnessing in Literature, Psychoanalysis, and History. By Shoshana Felmann and Dori Laub. New York: Routledge, 1991. 7592.

Leiser, Erwin. Pimpf war jeder. Berlin: Absolut Medien, 1998.

Lenz, Siegfried. Die Deutschstunde. Frankfurt: dtv, 2006.

Loftus, Elisabeth. Eyewitness Testimony. Cambridge: Harvard UP, 1996.

Mahlendorf, Ursula. The Shame of Survival: Working through a Nazi Childhood. Philadelphia: U Pennsylvania P, 2009.

Niven, Bill, ed. Germans as Victims: Remembering the Past in Contemporary Germany. Houndmills: Palgrave Macmillan, 2006.

Novick, Peter. The Holocaust in American Life. Boston: Mariner, 2000.

Reich-Ranicki, Marcel, ed. Meine Schulzeit im Dritten Reich. Erinnerungen deutscher Schriftsteller. Müunchen: dtv, 1998.

Schacter, Daniel. Searching for Memory: The Brain, the Mind, the Past. New York: Basic Books, 1996.

Schmitz, Helmut. On their Own Terms: The Legacy of National Socialism in Post-1990 German Fiction. Birmingham: U of Birmingham P, 2004.

Schumann, Willy. Being Present: Growing Up in Hitler's Germany. Kent: Kent State UP, 1991.

Wolf, Christa. Kindheitsmuster. Darmstadt: Luchterhand, 1977.

Wieviorka, Annette. The Era of the Witness. Transl. Jared Stark. Ithaca: Cornel UP, 2006.

Walser, Martin. Ein springender Brunnen. Frankfurt: Suhrkamp, 1998.

Weiss, Peter. Die Ermittlung. Oratorium in 11 Gesängen. Frankfurt: Surkamp, 1965.

Wicki, Bernhard. Die Brücke. Dover: Beta Film, 1998.

Zuckmeyer, Karl. Des Teufels General. Frankfurt: Fischer, 1958.

Author's profile: Anne Rothe teaches German cultural studies at Wayne State University. Her research of GermanJewish and East German culture is informed by theories of cultural memory and a critique of canonical trauma studies. Her publications include the articles "Das Dritte Reich als antifaschistischer Mythos im kollektiven Gedächtnis der DDR -- Christa Wolfs Kindheitsmuster als Teil- und Gegendiskurs," Deutsche Geschichte des 20. Jahrhunderts im Spiegel der deutschsprachigen Literatur (Ed. Moshe Zuckermann, 2003), "Literarische Revisionen der kollektiven Erinnerung an das sowjetische Exil in der (DDR-)Literatur nach 1989," Wissen -- Sprache -- Kultur - Europa (Ed. Yüksel Kocadoru, Kadriye Öztürk, Özlem Firtina, and Gülcan Çakır-Damaoğlu, 2006), and "The Third Reich and the Holocaust in East German Official Memory," Comparative Central European Holocaust Studies (Ed. Louise O. Vasvári and Steven Tötösy de Zepetnek, 2009). Currently, she is finishing an article entitled "Holocaust 
Anne Rothe,

"Between History and Memory in Schumann's Being Present: Growing Up in Hitler's Germany" page 12 of 12

CLCWeb: Comparative Literature and Culture 11.1 (2009): <http://docs.lib.purdue.edu/clcweb/vol11/iss1/6>

Thematic Issue New Work in Holocaust Studies. Ed. Louise O. Vasvári and Steven Tötösy de Zepetnek

Envy: Nonwitnesses and the Competition for Victim Status in Erica Fischer's Aimée und Jaguar." Her most recent project, a monograph tentatively entitled Trauma Culture: Emplotting the Pain of Others in the Therapeutic Age, expands her research beyond her home discipline of German studies into cultural and media studies. E-mail: <rothe@wayne.edu> 